\title{
A representação comercial soviética em face da legislação brasileira.
}

\author{
Loureiro Júnior \\ Docente livre de Direito Constitucional na \\ Faculdade de Direito da Universidade de \\ São Paulo.
}

\begin{abstract}
Sumário: 1. O Estado Socialista Russo. 2. Sentido da evolução econômica bolchevista. 3. O comércio exterior transformado em monopólio Estatal. 4. O protocolo como instrumento do acôrdo comercial.
\end{abstract}

O Govêrno dos Estados Unidos do Brasil convencionou, em Protocolo assinado a 20 de abril do corrente ano, que a Representação Comercial do Govêrno da União das Repúblicas Socialistas Soviéticas, ao exercer atividade mercantil em território brasileiro, gozará das seguintes imunidades, isenções e privilégios:

1. ${ }^{\circ}$ “A Representação Comercial da cidade do Rio de Janeiro gozará dos mesmos privilégios e imunidades concedidas às instalações das Missões Diplomáticas estrangeiras no Brasil" (art. $\left.1^{\circ}\right)$;

2. ${ }^{\circ}$ "O Chefe da Representação Comercial (o Representante Comercial), seus dois suplentes e demais funcionários da mesma, que constarem da "Lista Diplomática", gozarão dos mesmos privilégios e imunidades que, segundo o "Direito Internacional", são conce- 
didos aos funcionários da Embaixada da U.R.S.s. no Brasil" (art. 2. ${ }^{\circ}$ );

$\left.3 .^{\circ}\right)$ "A Representação Comercial não estará sujeita às leis e regulamentos sôbre o registro comercial" (art. 1. ${ }^{\circ}$ ); e

4. ${ }^{\circ}$ ) "A execução das sentenças jurídicas relativas às transações de que seja parte a Representação Comercial poderá incidir sôbre todos os bens do Estado Soviético no Brasil, particularmente sôbre os bens, direitos e interêsses oriundos das transações efetuadas ou garantidas pela Representação Comercial. Não incidirá, porém, sôbre os bens pertencentes às Organizações mencionadas no $\S 4$. $^{\circ}$ do art. $4 .^{\circ}$, que não houverem participado de transação garantida pela Representação Comercial. Segundo a praxe internacional, não serão objeto de procedimento judicial, de qualquer natureza, os bens e locais destinados exclusivamente ao funcionamento, no Brasil, da Embaixada da Representação Comercial e dos Consulados Soviéticos, bem como os móveis e pertences neles situados" $\left(\operatorname{art.} 5^{\circ}\right)$.

Os artigos acima foram transcritos do Protocolo publicado no "Diário do Comércio" de 18 de maio do corrente ano, São Paulo.

Torna-se imprescindível um exame preliminar e acurado das legislações soviética e brasileira e dos princípios e regras que regem o comércio exterior no plano internacional, a fim de que se possa, com a necessária segurança e indispensável fundamentação jurídica, concluir sôbre a legalidade e eficácia dessas concessões constantes do referido Protocolo, bem como da capacidade constitucional do agente executivo federal brasileiro para fazê-las, valen- 
do-se, ainda, do instrumento de que se utilizou. É o que se passa, agora, a verificar:

\section{O Estado Socialista Russo.}

O golpe revolucionário dos Sovietes instaurou na Rússia, em novembro de 1917, um novo tipo de govêrno ditatorial, que veio a se institucionalizar meses depois, com a publicação, em 10 de julho de 1918, da primeira Constituição da República Soviética Federativa da Rússia (R.S.F.S.R.).

O novo regime que passou a vigorar caracterizou-se, desde o início, pelas profundas e radicais transformações efetivadas na vida social, econômica, política e jurídica do país, conseqüência natural dos princípios ideológicos marxistas-leninistas inspiradores da insurreição recém-vitoriosa. Não se verificou, por isso, mera substituição de homens, grupos ou partidos políticos no comando das fôrças governamentais, sem o comprometimento dos rumos doutrinários que se vinham imprimindo aos negócios do Estado. Operou-se, ao contrário, uma inteira subversão dos antigos valores, com o predomínio de novos conceitos oriundos de uma mentalidade informada pelos postulados filosóficos do materialismo histórico.

São unânimes os juristas soviéticos em assinalar que, desde aquêle momento, e ainda em meio dos escombros do Império Russo, que soçobrara também em conseqüência das crises provenientes das derrotas militares sofridas na primeira guerra mundial, cuidou-se, desde logo, de erigir o Novo Estado em múltipla atividade de intenso dinamismo revolucionário. No conturbado e confuso horizonte daquele doloroso após-guerra, os Sovietes galgaram, assim, o poder com o firme e inequívoco propósito de realizar um programa de ação governamental rigorosamente preestabelecido, em que os objetivos se colimavam e se sucediam numa perfeita ordenação transformadora. 
Dragomir Issakovitch indicou, dessa maneira, as etapas iniciais :

"L'établissement des soviets, dont la base était imposée par les événements du commencement de 1905 est la nécessité logique déterminée par la destruction de la machine gouvernementale. L'organisation gouvernementale de l'état capitaliste, au moment où le prolétariat prend, le pouvoir doit être brisée et remplacée par l'organisation nouvelle sortis du prolétariat même, par laquelle doit être exercée la volonté formulée par la notion juridique: la dictature du prolétariat. Max et Engels dans le préface à la guerre civile en France disaient: "La classe ouvrière ne peut se borner à s'emparer d'une machine gouvernementale toute faite et la mettre en mouvement pour ses propres buts. La révolution prolétarienne ne doit pas, comme on l'a fait jusqu'à présent, transmettre la machine militaire bureaucratique d'une main dans une autre, mais la briser". Briser cette machine, la démolir, tel est le but pratique et immédiat de la construction soviétique. Lénine, s'appuyant sur la théorie marxiste et sur l'éxpérience historique disait: "La révolution prolétarienne est impossible sans la destruction violente de la machine gouvernementale bourgeoise et sans son remplacement par une nouvelle du peuple, de la majorité du peuple ouvrier et paysan" (LÉNINE, L'Etat et La Révolution Prolétarienne, p. 21).

Precisou, a seguir, os fins em mira:

"Voilà la tâche directe du système soviétique: la destruction du systéme gouvernemental capitaliste et la substitution d'un système nouveau: le soviet. Voilà l'idée générale constructrice dans la création du nouvel ordre gouvernemental. La révolution d'octobre n'avait pas pour but de transférer simplement la machine gouvernementale entre les mains du prolétariat, mais de la briser, de la détruire, pour qu'elle puisse après la recréer, la rebâtir d'après sa propre conception, sortie de la théorie générale socialiste. Or, la conséquence immédiate de la conquête du pouvoir 
par la classe prolétarienne, c'est la destruction de l'état capitaliste, la destruction de l'appareil gouvernemental, et la substitution d'un nouvel appareil, sorti de la force prolétarienne, capable de réaliser la dictature du prolétariat, capable d'unifier la force prolétarienne et de la mettre en marche.

La théorie marxiste a préconisé la nécessité de la destruction de la machine de l'État et la constitution du prolétariat dans la classe dominante, au moyen de la dictature du prolétariat, mais la théorie ne dit rien sur la forme de l'organisation ultérieure" (p. 21).

Esses ensinamentos encontram-se no livro Le Pouvoir Central et le Système Electoral de la Russie Soviétique, editado em Paris, no ano de 1927.

Os acontecimentos que, então, se verificaram foram apontados por ANDREI Y. Vishinsky na sua conhecida obra sôbre The Law of the Soviet State, New York, 1948, como prova de superioridade do regime soviético sôbre o parlamentar. Nesse sentido, afirmou:

"The experience of the Paris Commune of 1871, of the Russian Soviets in 1905, and of the great October Socialist Revolution (which during the twenty-one years of its existence has built a gigantic new socialist state of workers and peasants and a new culture, has produced all the conditions for the manifold development of toiling humanity's spiritual forces of creation, has raised the material wellbeing of the popular masses to a great height, and has brought up a whole generation of new Soviet people) serves as the best proof of all the advantages of the Soviet system over the parliamentary system. This is why the proletarian revolution does not strive to improve the bourgeois-democratic and in particular the parliamentary-state machinery, but shatters it with the iron hand of an upsurging proletariat and replaces it a new socialist state the state of the Soviets" (p. 74): 
Coube, no entanto, à primeira Constituição de 1918 estabelecer, de modo mais preciso, os objetivos a serem atingidos pelo Estado Socialista russo. Determinou, por isso, no seu Capítulo II, art. $3^{\circ}$ :

$1^{\circ}$ ) a socialização da terra, declarada propriedade nacional, suprimindo, dessa maneira, a propriedade privada;

$2^{\circ}$ ) a nacionalização dos bosques, do subsolo, das águas, tornando, ao mesmo tempo, também propriedade do Govêrno, todos os rebanhos e todo o material existente nas propriedades e emprêsas agrícolas, que também passaram a integrar o patrimônio estatal;

$\left.3^{\circ}{ }^{\circ}\right)$ a inspeção das fábricas, das minas, das estradas de ferro e outros meios de transporte e produção, como primeiro passo para a plena transferência de sua propriedade para a República dos Sovietes;

4. $\left.{ }^{\circ}\right)$ a anulação dos empréstimos feitos pelo antigo Govêrno e particulares aos proprictários de terra e ḋ burguesia, considerando tal providência como um primeiro golpe contra o capital internacional e formal garantia de que os Sovietes continuarão a agir dêsse modo até a vitória completa do proletariado internacional e sua libertação do jugo do Capital;

$\left.5^{\circ}\right)$ a transferência da propriedade de todos os Bancos, seus pertences $e$ haveres para o Estado, como uma das condições de libertação das massas trabalhadoras do jugo do Capital; 
6. ${ }^{\circ}$ a instituição do trabalho geral obrigatório como meio de suprimir os elementos parasitários da sociedade e organizar a vida econômica do país; e

7.') o armamento dos trabalhadores, a formação de um Exército vermelho socialista de operários e camponeses e o desarmamento completo das classes possuidoras.

Fixados, dessa forma, os supremos fins do Estado Socialista, a Constituição passou a organizar o poder público, como meio hábil e capaz para realizá-los.

Como havia ponderado Issakovirch, a teoria marxista preconizara "a necessidade da destruição da máquina do Estado" mas nada acrescentara sôbre "a forma da organização ulterior". Os juristas soviéticos tiveram, assim, de se valer dos princípios gerais para estruturar o novo aparelhamento estatal, utilizando-se, ao mesmo tempo, da própria experiência, haurida no contato das realidades ambientes e subordinada aos imperativos do momento.

Isso não impediu, porém, que pudessem, desde logo, registrar alguns traços definidores da nova teoria de Estado, que se formulava em esbôço. Duas tônicas fundamentais ficaram marcadas, justamente porque surgiam em declarado conflito com a clássica doutrina ocidental. Tratava-se da "concentração do poder" e da "extrema liberdade" que se lhe outorgava para agir segundo os ditames de sua própria vontade, empenhada na consecução dos fins estatais a serem atingidos por quaisquer meios ou formas.

Mostraram-se, aliás, unânimes os juristas soviéticos no repelir o sistema da divisão de poderes, que apontavam como técnica empregada pela burguesia para o enfraquecimento do Estado, a fim de que pudesse melhor sujeitá-lo aos interêsses da sociedade capitalista, sempre empenhada na espoliação da classe proletária. 
Desejando contrariar êsse resultado e com o intuito de fortalecer os Sovietes, empenharam-se, por isso, em assegurar a maior unidade possível à ação estatal. E tão longe foram nesse intuito que, mediante extremada concentração do poder público, realizaram nova modalidade de govêrno ditatorial. Esta circunstância não escapou a Perez Serrano que, no Ideario Bolchevista, Madrid, 1920, a menciona nesses termos:

“. . ni la separación entre Legislativo y Ejecutivo, ni la implantación de un régimen al uso occidental (parlamentario, verbigracia), resultan posibles en un sistema basado en el principio (transitorio, pero de duración no prevista) de la dictadura proletaria; como tampoco la pulcra demarcación entre la esfera política y económica, o, en otro orden, entre órbitas central y locales de poder. No se trata, pues, de un retoque a la ideología jurídica tradicional, ni de un cambio menudo en los métodos de producir y aplicar el derecho; se trata de una revolución en el sentido de hondura y ansia superadora que la palabra evoca".

Importante destacar que êste sentido unitário imprimiu, todavia, marcante organicidade aos fins do Estado, que passou, por sua vez, a ter maior expressão econômica do que política. Esta mudança determinou relevantes conseqüências e deve ser realçada para que se possa compreender, com exatidão, o sentido autêntico dos desenvolvimentos e transformações posteriores havidas nas atividades governamentais russas. Mirkine-Guetzevitch, no seu estudo sôbre La Théorie Générale de L'Etat Soviétique, Paris, 1928, explica o ocorrido:

"La doctrine soviétique primitive s'était déclarée solidaire de la conception marxiste des fonctions de l'État: si le matérialisme historique ni la valeur intrinsèque du Droit et de l'Etat, - si tout le processus historique se réduit à un phénomène écomique, "le gouvernement des individus, - selon Engels, est remplacé par la gérance des choses et par l'organisation des moyens de la production". Ainsi que l'écrivait Lénine, l'état co- 
n uniste se distingue par une grande simplification des fonctions gouvernementales, il est dépouillé de tous ses éléments politiques, il crée une organisation purement économique, dirigée par "les ouvriers, les surveillants, les comptables". Primauté du caractère politique (qui évoque dans un certain sens le proudhonisme) - tel était le point de vue officiel du bolchevisme primitif, en ce qui concerne la conception juridique de l'État. La réglementation minutieuse et rigoureuse de tous les aspects de la vie, l'étatisme outrancier du gouvernement soviétique évoquent le régime absolutiste du xvmre siècle. Cet État qui renonce peu à peu à la suppression de l'initiative privée, et qui est défendu par une armée et par une police politique aussi puissante que vigilante, - est un exemple de la primauté absolue des éléments politiques sur les éléments économiques. Nous nous heurtons ici à la profonde contradiction qui existe entre la théorie de l'État soviétique et la législation pratique. Cette théorie avait été crée en vue d'un État formé "d'ouvriers, de surveillants, de comptables", mais la législation pratique, c'est-à-dire, la vie a créé un organisme politique hypertrophié, qui domine entièrement l'appareil économique. En étudiant le droit public soviétique, il faut se rappeler sans cesse ces divergences profondes entre l'idéologie et la pratique; la théorie annonce la disparition de l'État politique au nom de la technique économique, en pratique, l'idée du pouvoir domine entièrement le vieux dogme de l'organisation économique".

Não é diverso e ensinamento de Linares Quintana:

"Se ha denominado con razón Estado económico total a la organización soviética rusa, ya que en ella se opera la economización del Estado, por la que se otorgan a éste exclusivas funciones económicas de dominación. Es decir, que el Estado, de sujeto político trasfórmase en sujeto económico. "El Estado soviético - afirma Sampay - es concebido como una suprema comunidad de producción y a quien mueve la fe en la omnipotencia de la técnica dirigida 
conforme a una economía planificada" (Derecho Constitucional Soviético, Buenos Aires, 1946, p. 30).

\section{Sentido da Evolução Econômica Bolchevista.}

Mostra-se inconteste a afirmativa de que a expressão econômica domina a fisionomia do novo Estado soviético. Éste o motivo que recomenda se observem as etapas do desenvolvimento econômico russo, a fim de que se precisem melhor os fins precípuos visados pelo poder estatal.

O govêrno soviético, que se instituiu em conseqüência da vitória do movimento revolucionário de outubro, teve de se deparar, desde os primeiros instantes, com inúmeros e variados problemas que lhe absorveram completamente a atenção e atividade. A nova ordem foi, porém, aos poucos se consolidando, de modo a tornar-se possível um escalonamento mais nítido das etapas a serem objetivadas.

O fim da guerra trouxe, também para a Rússia, várias e complexas questões que se formularam no campo da sua política exterior. E os efeitos, por si mesmos graves, da revolução interna, aumentaram ainda mais como resultante do bloqueio que lhe foi imposto pelo Conselho Supremo dos Aliados. Não pôde, por isso, a confusa e quase anárquica situação política interna, que padecia os reflexos de uma quase insuperável crise econômico-social, contar para a sua solução com quaisquer possíveis auxílios externos. Teve a Rússia bloqueada de encontrar, por si mesma, os rumos que a livrassem de suas dificuldades. Conseguiu, contudo, consolidar e fortalecer, passo a passo, o seu extraordinário poder político, fazendo com que o Partido Comunista - como bloco unitário de pensamento e ação, - superasse os múltiplos e heterogêneos Sovietes na orientação e comando do govêrno revolucionário.

A experiência demonstrou, ao mesmo tempo, que, sem a concentração do poder político nas mãos do Partido Comunista, tornavam-se inexequíveis as profundas reformas 
de caráter econômico, previstas na primeira Constituição, as quais visavam a socializar o aparelhamento $e$ os meios de produção. Comprovou-se, outrossim, a imperiosa necessidade de se prescrever uma rigorosa e metódica planificação para as atividades estatais.

Decorridos cêrca de quatro anos da vitória bolchevista, Lenine pronunciou memorável discurso, no $\mathrm{x}^{\circ}$ Congresso do Partido Comunista, realizado em 8 de março de 1921. Propôs, após profundo e realista balanço da situação russa, das atividades do Govêrno e do Partido, as novas metas que se revelavam indispensáveis ao pleno êxito da reconstrução empreendida. Esste Congresso, sob sua inspiração tomou três importantíssimas resoluções. A primeira relativa à "unidade do Partido", a segunda sôbre o "desvio sindicalista $e$ anarquista dentro do Partido Comunista" e, finalmente, a terceira referente à denominada "nova politica econômica" - NEP.

A última decisão interessa ao presente estudo porque a NEP pode ser considerada o primeiro ponto fixo e orgânico da posterior evolução econômica bolchevista. A NEP significou importante alteração de rumo e deu resultados de relêvo, embora se tivesse anunciado o seu caráter transitório.

Foi em virtude da NEP que se permitiu, de certa forma, o reinício do comércio privado, autorizando-se ainda os particulares reabrirem pequenas emprêsas industriais. Isso se deu porque a NEP substituiu o vigente "regime de contribuição por quotas" por um "novo regime de impôsto em espécie". Como o volume dêste impôsto era menor do que o das quotas, após o seu pagamento restavam ainda produtos e mercadorias em poder do contribuinte, que teve permissão para comerciar com essas sobras havidas. Ao propor a instituição da NEP, reconheceu LENINE que "a princípio, a liberdade de venda se traduziria em uma certa reanimação do capitalismo dentro do país". O líder comunista justificou, dessa forma, a sua proposição: 
"Não havia porém motivo para ter mêdo a isto. Lenine entendia que uma certa liberdade de circulação de mercadorias estimularia o interêsse econômico do camponês, incrementaria a produtividade do seu trabalho e elevaria ràpidamente o rendimento da agricultura; que sôbre esta base se restauraria a indústria do Estado e se desalojaria o capital privado; que depois de acumular fôrças e recursos, se poderia criar uma potente indústria, base econômica para o socialismo, e logo depois passar decididamente d̀ ofensiva, para destruir os restos do capitalismo dentro do país" (História do Partido Comunista da u.R.s.s., Editorial Vitória Ltd. .., Rio de Janeiro, 1945, p. 359).

O historiador oficial, no compêndio acima referido, aprovado pelo Comitê Central do Partido Comunista, assim se refere à nova política econômica:

"A mudança para a NEP fortaleceu consideràvelmente a aliança entre os operários e os camponeses, sôbre uma nova base. Aumentaram a potência e a fortaleza da ditadura do proletariado. Liqüidou-se quase totalmente o banditismo dos "kulaks." Depois da abolição do sistema de quotas, os camponeses médios ajudaram o Poder Soviético a lutar contra aquêles bandos. O Poder Soviético conservava nas suas mãos tôdas as posições de direção da Economia nacional: a grande indústria, os transportes, os bancos, a terra, o comércio interno e externo. 0 Partido conseguiu mudar decisivamente a frente econômica. Manifestaram-se os primeiros êxitos no campo da indústria e dos transportes. Iniciou-se um avanço, lento no comêço, é certo, porém indubitável, no terreno da Economia. Os operários e os camponeses sentiam e viam que o Partido estava em bom caminho" (p. 363).

Mui valiosa esta declaração:

"Neste período (início da NEP), o elo fundamental da cadeia de tarefas que se apresentavam ao Partido era o comércio. Sem resolver êste problema era impossível desenvolver o intercâmbio de mercadorias entre a cidade e o 
campo, era impossível fortalecer a aliança econômica entre os operários e os camponeses, era impossível levantar a economia rural e tirar do marasmo a indústria.

Naquele momento, o comércio soviético era ainda muito débil. $\mathrm{O}$ aparelho comercial era muito fraco, os comunistas não tinham hábitos comerciais, ainda não conheciam a fundo o inimigo - "nepman", nem tinham aprendido a lutar contra êle. Os comerciantes privados, os "nepman", aproveitando-se da debilidade do comércio soviético, se apoderaram do comércio dos artigos manufaturados e de outras mercadorias de fácil colocação. $O$ problema da organização de um comércio de Estado e de um comércio cooperativo adquiria uma imensa importância" (p. 364).

Os responsáveis por esta nova política econômica russa proclamaram, desde quando a estabeleceram, o seu caráter eminentemente transacional e tático. Faziam empenho em esclarecer que esta nova política correspondia tão-só a um imperativo momentâneo.

A passageira referência ao comércio exterior bolchevista, feita pelo historiador oficial em sua apreciação dos resultados da NEP, não poderia, de fato, ter maior ênfase. A Rússia estava apenas reiniciando suas ligações com o exterior. O Conselho Supremo dos Aliados sòmente em janeiro de 1920 levantara o bloqueio militar, consentindolhe retomasse, dai por diante, o contato comercial com os demais países. As fortes crises e enormes dificuldades internas não lhe possibilitavam, contudo, imprimisse maior expansão às suas atividades no comércio internacional. Eram até mesmo raros e incipientes os preceitos legais que re referiam à matéria comercial.

A primeira Constituição atribuíra, no art. 49, letra "i", de um modo vago, competência ao Congresso dos Sovietes e ao Comitê Central Executivo para estipular "convênios aduaneiros $e$ comerciais $e$ acordos financeiros". E, no art. 43, instituíra o "Comissariado do Povo para o Comércio e Indústria". 
Antes, porém, segundo Freund, um decreto de 28 de abril de 1918 já teria estabelecido que:

"Tout le commerce extérieur est monopolisé. Les marchés commerciaux d'achat et de vente de toutes sortes de produits avec les États étrangers et des établissements de commerce à l'étranger ne seront traités qu'au nom de la République Russe par des organes spécialment autorisés à cet effet. Toutes affaires commerciales avec l'étranger concernant l'importation et l'exportation, en dehors de ces organes, sont interdites" (Journal de Droit International, 1934, p. 10).

Há, todavia, datada de 13 de março de 1922, uma resolução do Comitê Central Executivo, declarando "o comércio exterior monopólio do Estado" (SANTa Pinter, Sistema del Derecho Soviético, Buenos Aires, 1957, p. 56).

Limitou-se a segunda Constituição Soviética, de 6 de julho de 1923, a dar competência, no art. 1. ${ }^{\circ}$, letra "g", aos órgãos supremos da União das Repúblicas Socialistas Soviéticas para "dirigir o comércio exterior e determinar o regime do interior".

Estabeleceu, ainda, no art. 37, que o Comissário Popular do Comércio Exterior integrava o Conselho dos Comissários do Povo, órgão executivo do Comitê Central da União.

Classificou, no art. 50, o Comissariado do Comércio Exterior dentre os Comissariados Gerais, únicos para todo o território da União. Colocou-o, assim, ao lado dos Comissariados para Assuntos Estrangeiros, Guerra e Marinha, Vias e Comunicações e Correios e Telégrafos.

Patenteia-se, dessa maneira, a grande importância que já se estava começando a conceder ao Comissariado do Comércio Exterior, elevado à categoria de órgão único, com exercício em todo o território da União.

Pode-se pretender que a morte de Lenine, em janeiro de 1924, marque o fim da primeira etapa da revolução socialista russa. 
Desde então, até que STalin, através do completo domínio do Partido Comunista Russo, se apodere do Govêrno Soviético, surgem os primeiros indícios de novas e profundas transformações revolucionárias.

Iria se verificar o fortalecimento do Estado em tôdas as suas atividades e, principalmente, no setor econômico, onde se deveria, de novo, suplantar a iniciativa e a ação privadas.

Com êsse intuito, o xuI. ${ }^{\circ}$ Congresso do Partido, realizado em maio de 1924, aprovou "a criação do Comissariado do Povo para o Comércio Interior e propôs a todos os organismos comerciais a tarefa de dominar o mercado $e$ desalojar da órbita comercial o capital privado" (História do P. C., p. 378).

Discutiu-se longamente a maneira de como se deveria proceder e perquiriu-se da possibilidade do definitivo estabelecimento de uma economia socializada, focalizando-se, ainda, a hipótese de um regresso, embora parcial, ao sistema capitalista econômico. Venceu o propósito de se edificar uma economia socialista. Assim a referida História do Partido Comunista registra o decidido:

"Sim - respondia o Partido - o País Soviético pode e deve edificar uma Economia Socialista, pois existem nele todos os elementos necessários para isto, para construir uma Economia Socialista e para edificar uma sociedade socialista completa. Em outubro de 1917 a classe operária venceu o capitalismo no terreno político, instaurando sua ditadura política. De então para cá, o Poder Soviético tomou tôdas as medidas necessárias para destruir a potência econômica do capitalismo e criar as condições indispensáveis para edificar uma economia nacional de tipo socialista. A expropriação dos capitalistas e latifundiários, a conversão das terras, fábricas e emprêsas industriais, bancos e vias de comunicação, em propriedade de todo o povo; a implantação da nova política econômica; a organização de uma indústria socialista do Estado; a aplicação 
do plano cooperativo de LENINE: eis aí as medidas adotadas pelo Poder Soviético. A tarefa fundamental, agora, consiste em desenvolver por todo o país a obra de edificação de uma nova Economia, da Economia Socialista, dando também assim o tiro de misericórdia no capitalismo no terreno econômico" (p. 382).

O Estado passou nesse intuito a interferir e a controlar, de modo direto, também o Comércio Interno. A própria Constituição foi reformada, em 24 de outubro de 1924, tendo se modificado os seus arts. 37 e 64, em que se substituíu o "Comissariado do Povo para o Abastecimento" pelo "Comissariado do Povo para o Comércio Interno" (MrRkiNE-GueTZEviTch, opus cit., p. 170).

No desejo, sem dúvida, de tornar mais completo e decisivo o contrôle estatal, o Comitê Central Executivo e o Conselho dos Comissários do Povo resolveram, em 18 de novembro de 1925, reunir o Comissariado do Povo do Comércio Interior e o Comissariado do Povo do Comércio Exterior em novo órgão: o Comissariado do Povo para o Comércio Exterior e Interior da União das U.R.S.s. (MirisineGuetzevitch, opus cit., p. 174).

Caracterizaram o xiv..$^{\circ}$ Congresso do Partido, em dezembro de 1925 , a violenta luta política interna pela eliminação do trotskismo e o vigoroso afã pela industrialização socialista do país. Os comunistas haviam compreendido, enfim, que só mediante um acelerado processo industrial conseguiriam atingir maior grau de desenvolvimento econômico.

Por volta de 1927 já se faziam sentir, de maneira nítida, os resultados da nova orientação, cuja conseqüência estava sendo, também, o progressivo e marcante aniqüilamento do setor econômico privado. O historiador oficial refere-se, dessa forma, a êste período:

" $O$ setor socialista da indústria crescia ràpidamente $a$ expensas do setor privado, aumentando de 81 por cento em 1924-1925, até 86 por cento em 1926-1927, ao mesmo 
tempo que o pêso específico do setor privado decrescia, durante êste período, de 19 a 14 por cento.

Isto significava que a industrialização na u.R.s.s., de caráter socialista, ia se acentuando ràpidamente e que, no terreno da indústria, o problema do "quem vencerá?" estava já resolvido a favor do socialismo.

Com a mesma rapidez os comerciantes privados iam sendo desalojados do comércio; sua participação no comércio retalhista decresceu de 42 por cento, em 1924-1925, a 32 por cento em 1926-192\%, e nâo falemos no comércio atacadista, onde a participação dos particulares desceu, nesse mesmo periodo, de 9 a 5 por cento.

Era, porém, mais rápido ainda o rítmo com que se desenvolvia a grande indústria socialista, que em 1927, isto é, no primeiro ano depois do período de restauração da Economia, viu aumentar sua produção de 18 por cento, em comparação com a do ano precedente. Era êste um recorde de desenvolvimento da produção, inexequível até para a grande indústria dos países capitalistas mais adiantados" (p. 402).

O expressivo impulso verificado com a industrialização levou os líderes comunistas a volverem suas vistas para o problema agrário, que se tem mostrado mui complexo, cheio de dificuldades e que até hoje desafia-lhes a argúcia e competência.

Coube ao xv. ${ }^{\circ}$ Congresso do Partido, em 2 de dezembro de 1927, enfrentar tal tarefa. Foi tomada " $a$ resolução de desenvolver por todos os meios a obra de coletivização da agricultura. Traçou um plano para desenvolver e consolidar uma rêde de "kolkoses" e "sovkoses" e deu instrucỗes claras e precisas sôbre os métodos de luta em prol da coletivização da agricultura" (História do P.C., p. 405).

Estava chegando ao seu têrmo a fase das marchas e contramarchas experimentais. Já eram mui diminutas as resistências ao poder absorvente e dominador do Estado. Formava-se, pouco e pouco, uma competente elite técnica, 
incumbida de estabelecer, com segurança e conhecimento, os programas a serem seguidos em tôdas as iniciativas e trabalhos governamentais. Atingia-se o grande momento das planificações socialistas.

O xvr. ${ }^{\circ}$ Congresso do Partido, em abril de 1929, aprovou a execução do primeiro "Plano Qüinqüenal" e o xvir. $^{\circ}$ Congresso do Partido, reunido em janeiro de 1934, adotou o segundo "Plano Qüinqüenal". Importante registrar que "por essa época, a indústria socialista constituía já $99 \%$ de tôda a indústria do país. A agricultura socialista - os "kolkoses" e os "sovkoses" - englobavam cêrca de $90 \%$ da superfície total semeada do país. No que se refere à circulação de mercadorias, os elementos capitalistas tinham sido desalojados totalmente do comércio" (História do $P$. C., p. 449).

Foram assim designados os fins do segundo "Plano Qüinqüenal":

"As tarefas fundamentais do segundo Plano Qüinqüenal - a liqüidação definitiva dos elementos capitalistas, a superação das sobrevivências do capitalismo na economia e na consciência dos homens, o remate da obra de reconstrução de tôda a Economia nacional sôbre a base da técnica mais moderna, a assimilação da nova técnica e da direção das novas emprêsas, a mecanização da agricultura e a elevação de sua produtividade - criam com tôda sua fôrça o problema de elevar a qualidade do trabalho em todos os setores e, em primeiro lugar, a qualidade da direção prática em matéria de organização" (História do P. C., p. 454).

Quando se cuidou, em novembro de 1936 , no xvirr. ${ }^{\circ}$ Congresso da U.R.s.s., da mudança da Constituição de 1924, Stalin ao se manifestar sôbre a nova Constituição posta em vigor, fêz um interessante confronto entre êstes dois periodos históricos, registrando as tarefas realizadas e os respectivos alvos propostos.

A História do Partido Comunista faz a sintese do seu informe, nesses têrmos: 
“A Constituição de 1924 havia sido redigida no primeiro período da NEP. Naquele momento, o Poder Soviético consentia ainda no desenvolvimento do capitalismo paralelamente ao do Socialismo. Naquele momento, o Poder Soviético esperava que, no curso da emulação entre os dois sistemas - o sistema capitalista e o sistema socialista, - se organizasse e fôsse garantido o triunfo do socialismo sôbre o capitalismo no terreno econômico. Naquele momento, não estava decidido ainda o problema de "quem vencerá". A indústria, baseada em uma técnica velha e pobre, não tinha alcançado sequer o nível de antes da guerra. E ainda menos animador era o quadro que oferecia, naquela ocasião, a agricultura. Os "sovkoses" e os "kolkoses" eram como ilhotas isoladas no meio do imenso oceano das explorações camponesas individuais. A luta contra os "kulaks" não visava ainda sua liqüidação, mas apenas a sua limitação. No terreno da circulação de mercadorias, o setor socialista só representava, aproximadamente, uns 50 por cento.

Em 1936, a U.R.S.s. apresentava já um panorama diferente. A Economia da U.R.S.s. havia mudado radicalmente. Por esta época, haviam sido totalmente liqüidados os elementos capitalistas, e o sistema socialista havia triunfado em todos os ramos da Economia nacional. A potente indústria socialista ultrapassava sete vêzes a produção de antes da guerra e tinha desalojado completamente a indústria privada. Na agricultura, havia triunfado com os "kolkoses" e os "sovkoses" a maior produção socialista do mundo, uma produção mecanizada e equipada como nenhuma outra, segundo a técnica. Os "kulaks" haviam sido totalmente liqüidados como classe, e o setor individual já não desempenhava nenhum papel importante na Economia do país. Tôda a circulação de mercadorias estava concentrada em mãos do Estado e das cooperativas. A exploração do homem pelo homem havia sido destruída para sempre. A propriedade social, socialista, sôbre os meios 
de produção se havia consolidado como base inquebrantável no novo regime socialista, em todos os ramos da Economia nacional" (p. 481).

A Constituição de 1936 estabeleceu, então, na letra "g" do art. 14, que "o Comércio Exterior se faria sôbre a base do monopólio do Estado".

Colocou, no art. 77, entre os Comissariados do Povo, de caráter federal, o do Comércio Exterior. Ficou ao lado dos Comissariados da Defesa, dos Negócios Estrangeiros e das Vias e Comunicações, das Comunicações Postais e Elétricas, de Transporte por Água e da Indústria Pesada. Esta circunstância, por si só, marca-lhe o grande destaque.

Mais tarde, o Soviete Supremo, em março de 1946, substituíu as denominações "Comissariado do Povo" e "Comissário do Povo" pelas de "Ministério" e "Ministro" (Constituciones Vigentes, Buenos Aires, Lajouane Editôres, p. 267).

Como se assinalou, encerravam-se as fases das improvisações. Os rumos haviam sido fixados e os sucessivos "planos qüinqüenais" complementavam-se, no afã de lograr em ritmo acelerado a preestabelecida socialização total da Economia russa.

Vyshinsky, em capitulo referente a The Social Organization of the U.R.s.s., expõe, em minúcia, o significado do processo do "State planning of the national economic life of the U.R.s.s." e cita, no seu mencionado livro, como certa vez Stalrn definiu, com alguma ironia, a nova situação:

"But the capitalist state is little concerned with economy in the proper sense of the word - economy is not in the hands of the state - on the contrary the state is in the hands of capitalist economy" (p. 281).

O Estado, no sistema soviético, ficou, na verdade, em mãos da Economia russa, dela se tornando quase mera expressão. O posterior desenvolvimento do processo evolutivo econômico socialista, seguiu o sentido já plenamente 
fixado e, por isso, perde maior interêsse para a indagação que se vem formulando.

A matéria exposta já é mui suficiente para que se possa, com segurança e acêrto, passar ao estudo do tema específico do presente trabalho. Foi, sem dúvida, imprescindível a indagação feita, embora fora do terreno especificamente jurídico, porque como muito bem ensina o Professor Vicente RÁo “é impossível examinar-se o Direito Soviético, sem subordiná-lo ao sistema político-econômico, de que faz parte. Suas peculiaridades e sua singularidade não permitem um estudo comparativo puro e simples, com o Direito ocidental. É indispensável, portanto, recordar, sumàriamente embora, os princípios fundamentais e inspiradores dessa nova concepção, dêsse novo sistema de Leis" (O Direito e a Vida dos Direitos, vol. 1. , p. 154).

\section{O Comércio Exterior como Monopólio Estatal.}

Não seria possivel à Rússia Soviética manter-se sempre afastada do convívio internacional. Por isso, depois que o Conselho Supremo dos Aliados libertou-a do bloqueio militar, reiniciou os seus contatos com as demais Nações. Daí os seus primeiros entendimentos com os países limítrofes e os acordos e tratados firmados para o restabelecimento do seu comércio exterior. Desde as suas primeiras manifestações ficou, no entanto, patente o seu inequívoco propósito de atuar com sentido nitidamente revolucionário também no campo internacional. Esta peculiaridade não escapou à observação de Mirkine-Guetzevitch, que afirmou na sua citada obra:

"La doctrine soviétique ne fait donc pas qu'interpréter son droit; elle "annonce encore une véritable guerre civile au front juridique", comme s'exprime un des commentateurs; elle invite non seulement à rejeter les formes de l'État occidental, mais encore à procéder $\dot{\alpha}$ une révision et 
à une critique résolue de toutes les conceptions juridiques, en commençant par l'idée même du droit" (p. 135).

Quem previra, todavia, que a doutrina comunista promoveria uma "verdadeira guerra civil no front jurídico" foi o próprio jurista soviético sтoutchKa, no seu livro sôbre Le Rôle Révolutionnaire du Droit et de l'État.

Basta lembrar que, até então, o comércio exterior se fazia de acôrdo com princípios, regras e costumes que regiam a matéria e eram, pacificamente, aceitos por todos os paises, sem a menor relutância ou dificuldade. Os interêsses privados dominavam sempre essas transações, que se efetuavam segundo os princípios comuns e normais do Direito Internacional Privado e do direito interno.

As relações entre os Estados promoviam-se, no plano internacional, através de seus representantes, divididos em duas categorias: diplomáticos e administrativos.

A representação diplomática expressava a própria soberania estatal, enquanto que a administrativa exprimia os interêsses, de natureza não política, dos Estados ou dos seus súditos, pelos quais, também, lhe competia zelar. $\mathrm{O}$ exercício da primeira missão assegurava aos seus agentes certos privilégios, imunidades e regalias - imunidade de jurisdição local, inviolabilidade da pessoa, da correspondência, da residência e da sede da representação, isenção de impostos, - em conseqüência do alto e relevante papel que desempenhavam.

Os segundos já não desfrutavam idêntica situação e nem usufruíam garantias específicas tão latas para o exercício de suas funções.

A Missão Diplomática distinguia-se claramente do Serviço Consular, subordinando-se à classificação dos agentes diplomáticos e regulamentos internacionais, ao passo que a dos funcionários consulares cabia, simplesmente, a cada Estado.

Os Cônsules não exerciam, pròpriamente, atividades mercantis. Essas eram atribuidas a representantes espe- 
ciais que não gozavam, no seu desempenho, de privilégios, imunidades ou regalias diplomáticas.

Êste o quadro clássico de representação estrangeira aceito, sem discrepâncias nem controvérsias, por tôdas as Nações.

A volta da Rússia ao convívio internacional provocou, porém, inequívoco abalo e modificação revolucionária nessa estruturação pacificamente vigente.

A primeira e profunda mudança decorreu do fato de haver a Rússia declarado o comércio exterior monopólio estatal.

Esta determinação, por si só, fêz surgir complexos e profundos problemas jurídicos. Procurou a Rússia, desta forma, outorgar uma injustificável posição de privilégio ao seu comércio exterior, querendo exercê-lo como expressão da própria soberania estatal. Numa conceituação híbrida e inadmissível para os países ocidentais, pretendeu assim transformar as atividades comerciais, que são, sem dúvida, objetos específicos do direito privado, em atos de soberania que só se compreendem no plano das relações internacionais, entre Estados. A singularidade desta chocante e contraditória construção jurídica foi, desde logo, repelida nos círculos jurídicos não soviéticos. Conseguiu a Rússia, apesar disso, sempre através de tratados bilaterais, impor a sua decisão revolucionária à transigência de vários países, desprevenidos e desavisados, que assim se submetiam à sua sábia estratégia, inspirada sobretudo em considerações sociais e políticas, como registrou Freund. Êste ilustre jurista alemão apontou com nitidez o objetivo comunista:

"Le monopole du commerce extérieur permettait également d'obtenir les meilleures conditions en contractant des marchés à l'étranger, ainsi que d'utiliser la situation monopoliste de l'État sur tous les marchés étrangers comme instrument de haute politique, en mettant les Etats en concurrence les uns avec les autres. 
C'est ainsi qu'on a fait du monopole du commerce étranger une des positions dominantes de l'État: il figure comme tel dans la Constitution de l'U.R.s.s." (Journal du Droit International 1934, p. 8).

MarX e LENINe repetiram, várias vêzes, em seus ensinamentos táticos, que era indispensável para a Rússia comunista promover e valer-se das crises e contradições do capitalismo para que pudesse, finalmente, assegurar o triunfo internacional da revolução bolchevista.

Não há dúvida de que o monopólio do comércio exterior tenha sido um dos objetivos específicos do Comunismo.

SÉrgIo KRYlov, em artigo sôbre La doctrine soviétique $d u$ Droit International, publicado no Recueil des Cours de l'Académie de Droit International, vol. 70, comprova a assertiva:

"Aux xive et $\mathrm{xv}^{\mathrm{e}}$ Congrès communistes, J. V. Staline a défini comme tâche principale la consolidation du commerce extérieur de l'u.R.S.s., c'est-à-dire la concentration de tout le commerce extérieur entre les mains de l'État soviétique, le développement des relations économiques avec les pays capitalistes. Les trois Congrès suivants (Xvi ${ }^{\mathrm{e}}$, $\mathrm{XVII}^{\mathrm{e}}$ et $\mathrm{XVIII}^{\mathrm{e}}$ ) ont mis au point la formule bien connue de J. V. Staline affirmant que la politique de l'U.R.S.s. est une politique de renforcement des relations commerciales avec tous les pays. Sous la réserve de l'immuabilité du monopole d'Etat dans le commerce extérieur de l'u.R.s.s., cette recherche a déterminé les termes d'une série d'accords relatifs au commerce extérieur de l'v.R.s.s., durant la Grande Guerre de 1941-1945 aussi bien que dans la période d'aprèsguerre où apparaissent les derniers traités internationaux conclus par l'Union Soviétique en 1947" (p. 427).

Note-se que acentuou ser imutável o monopólio estatal do comércio exterior russo. Éste representante soviético na Côrte Internacional de Justiça finaliza o mencionado estudo com esta importantíssima declaração: 
"Ainsi il faut considérer le droit soviétique comme un des instruments de la refonte de la société humaine sur les bases socialistes, de la formation d'une nouvelle société socialiste, d'une nouvelle culture socialiste" (p. 474).

Está, portanto, marcada, por uma voz insuspeita, $a$ finalidade bolchevista. O Direito soviético é considerado mero instrumento da reestruturação da sociedade humana sob bases socialistas. A concepção instrumental do Direito e do Estado na doutrina soviética foi sempre generalizada e tranqüila porque decorre dos próprios fundamentos ideológicos do marxismo.

Estabelecido o monopólio estatal do comércio exterior, criou a Rússia órgãos adequados para promovê-lo, fixando-lhes os meios de atuação. Os novos organismos destinados a êste fim receberam o nome de Representações Comerciais Soviéticas. Freund mencionou as dificuldades de se acompanhar a evolução legislativa dêsses novos organismos. Seus lineamentos encontram-se assentados em legislação esparsa e de difícil acesso. Este aspecto do problema não tem, contudo, maior importância para a presente cogitação.

Dá-se o contrário quanto às funções das Representações Comerciais, que Alexandre Makarov, no seu artigo sôbre a Conception du Droit International Privé d'après la doctrine et la pratique russes, assim especifica:

"Les représentations commerciales ont deux catégories de fonctions: $10^{\circ}$ - les fonctions régulatrices; $2 .^{\circ}-$ les fonctions commerciales. Les fonctions régulatrices correspondent aux fonctions des consuls en matière de commerce, ainsi que des agentes commerciaux spéciaux. Ce qui fait la particularité des représentations commerciales, c'est l'activité commerciale qu'elles exercent. En exerçant cette activité, les représentations commerciales apparaissent sur le marché étranger comme les organes de l'État-commerçant, comme les organes de l'Etat prenant part au commerce sur le même pied qu'un commerçant privé" (Recueil 
des Cours de l'Académie de Droit International, vol. 35, p. 533).

Não é, porém, uniforme a maneira como são exercidas essas funções, que se encontram, principalmente, regulamentadas em tratados bilaterais. Apesar dessa circunstância, o jurista FREUND procurou, no seu citado artigo, selecionar alguns problemas já generalizados, em conseqüência das atividades das Representações Comerciais. São os seguintes: a agregação das Representações Comerciais às Embaixadas, a personalidade jurídica das Representações Comerciais e a submissão das Representações Comerciais às jurisdições do país.

Será profícuo seguir-se o critério adotado para o reexame dessas questões, valendo-se, ainda, para o seu completo esclarecimento, da contribuição trazida por outros eminentes juristas e considerando-se, ao mesmo tempo e a cada passo, o que ficou estabelecido no Protocolo brasileiro.

\section{a) Agregação das Representações Comerciais às Embaixadas.}

A Rússia, subvertendo tôdas as normas aceitas para a representação dos Estados no estrangeiro, empenhou-se em conseguir fôsse reconhecido caráter diplomático à sua Representação Comercial. Não logrou, contudo, êste seu propósito inteiramente descabido. Mas conseguiu, através de uma forma transacional, realizar de certa maneira os seus intentos. Êste seu propósito causou desde logo espécie, porque as demais Nações não podiam sinceramente compreender os motivos alegados para justificá-lo. Jamais se pretendera sequer igualar os representantes comerciais aos cônsules e, muito menos, aos membros da Missão Diplomática. Admitira-se, é certo, com a criação de determinados organismos coletivos internacionais, fôssem os seus agentes ou os representantes dos Estados dêles partícipes, equiparados aos membros da Missão Diplomática para os efeitos de desfrutar as mesmas prerrogativas, privilégios e imuni- 
dades. Não se havia, contudo, em tempo algum cogitado de colocar simples agentes comerciais em tão elevada categoria. Nem se podia entender que o exercício da atividade mercantil comum requeresse garantias de tamanha monta.

Levantou-se por isso, em tôda parte, séria e fundamentada suspeita sôbre as exatas natureza e finalidades das funções que os Representantes Comerciais russos pretendiam desempenhar nos países estrangeiros. Por êsse motivo, todos os países, ao firmarem tratados de comércio exterior com a Rússia, focalizaram com muito cuidado e prudência esta sua estranha pretensão.

Sem que a mesma tivesse sido completamente atendida, acabou-se, mediante uma forma de compromisso, por consentir que o Chefe e os principais membros da Representação Comercial russa usufruíssem alguns dos referidos privilégios, bem como se concedeu extraterritorialidade às sedes e estabelecimentos principais da Representação Comercial soviética. A extensão dessas concessões variou, porém, de país a país, de tratado a tratado. Esta transigência resultou, sobretudo, da circunstância de haver a Rússia integrado a sua Representação Comercial no corpo da sua Embaixada, embora aquela continuasse subordinada ao Ministério do Comércio Exterior soviético.

Freund declara, no seu mencionado artigo, que em nenhum dos vários tratados em vigência, o Govêrno soviético obteve o reconhecimento de completa extraterritorialidade para os locais ocupados pela sua Representaçâo Comercial e nem foi aceita a completa incorporação desta $\dot{a}$ Embaixada russa.

Trachtenberg, em artigo sôbre Le statut de la représentation commerciale de l'U.R.s.s. en France", publicado na Nouvelle Revue de Droit International Privé, 1924, tomo $1 .^{\circ}$, manifesta-se dêsse modo quanto a essas pretensões comunistas: 
"Le gouvernement de l'U.R.s.s. s'est toujours efforcé de faire connaître les représentations commerciales comme partie intégrante de ses ambassades, dans le but de les faire bénéficier de tous les avantages diplomatiques attribués à celles-ci. Dans ce même but, il a introduit cette disposition dans sa législation interne. Cette prétention ne parait, cependant, pas justifiées dans les rapports internationaux, étant donnée que les représentations commerciales cumulent des fonctions administratives avec une activilé purement commerciale, laquelle, conformément au droit non soviétique, n'a aucun rapport avec la souveraineté de l'État. Par ailleurs, les représentations commerciales comprennent généralement un nombre considérable de personnes qui même du point de vue soviétique, sont de simples employés commerciaux, n'ayant ni rang ni fonctions diplomatiques. Aussi, généralement, le point de vue du gouvernement de l'U.R.s.s. n'a pas été admis intégralement par les États contractants et l'on a habituellement adopté une formule transactionnelle, d'après laquelle la représentation commerciale est “attachés" à l'Ambassade de l'v.R.s.s." (p. 32).

O Protocolo brasileiro fixou, a êsse respeito, no art. 1. ${ }^{\circ}$, que "a Representação Comercial da cidade do Rio de Janeiro gozará dos mesmos privilégios e imunidades concedidas às instalações das Missões Diplomáticas estrangeiras no Brasil".

Determinou, no art. 2. ${ }^{\circ}$, que "o Chefe da Representação Comercial (o representante comercial), seus dois suplentes e demais funcionários da mesma que constarem da "Lista Diplomática" gozarão dos mesmos privilégios e imunidades que, segundo o Direito Internacional, são concedidos aos funcionários da Embaixada da u.R.S.s. no Brasil".

Como se verifica, o Protocolo brasileiro cedeu nesse ponto, inteiramente, às exigências russas. Ao invés de limitar, de modo expresso, o número dos integrantes da Representação Comercial soviética que iriam gozar das re- 
galias diplomáticas, entregou ḋ própria Rússia esta relevante incumbência.

Mais cuidadosos e prudentes foram os Governos da Noruega, Suécia e Alemanha. O primeiro concedeu a equiparação diplomática apenas ao dirigente da Representação Comercial; o segundo, ao Chefe da Representação e ao seu Adjunto, e o terceiro, ao Chefe da Representação e aos seus dois Adjuntos. Mostraram-se, também, cautelosos os Governos da Itália, Estônia, Grécia, Inglaterra e Lituânia, que consideraram como membros da Embaixada russa o Chefe da Representação Comercial, o seu, ou os seus Adjuntos, e, eventualmente, os membros do Conselho. O Govêrno da Tchecoslováquia outorgou prerrogativas diplomáticas apenas ao Chefe da Representação Comercial e o Govêrno da França ao Chefe e aos seus dois Adjuntos.

Mas, não é só. O Protocolo brasileiro foi muito além e, ainda no art. $2 .^{\circ}$, estipulou que "os cidadãos soviéticos enviados ao Brasil, para servirem como funcionários da Representação Comercial, estarão isentos do Impôsto de Renda sôbre os salários que perceberem do Govêrno soviético pela execução das funções previstas no art. $3 .^{\circ}$ ".

Note-se que, dentre as atividades referidas nesse artigo, encontra-se o exercício da atividade mercantil. Equiparou-se, portanto, a Representação Comercial à Missão Diplomática, e, como adiante se verificará, as exceções fixadas posteriormente não alteraram, de modo substancial, o que já fôra feito.

b) Personalidade Jurídica das Representações Comerciais.

Ficou já referido que, como a Rússia tivesse monopolizado o seu comércio exterior, veio a pleitear, em conseqüência, que os demais países reconhecessem que o seu exercício, feito através de organismo especial, constituísse também expressão da soberania nacional soviética. Terse-ia de conferir, dêste modo, capacidade especial para que o Estado soviético exercesse, no âmbito interno dos países 
no curso de seus negócios, uma ação monopolística, de caráter estatal. Pretendia, pois, o Estado soviético interferir, como tal, no círculo privado das demais Nações, praticando, de modo singular e vantajoso, atos de comércio que sempre foram regidos pelas regras do direito interno nacional e do direito internacional privado.

Esta pretensão russa criou árduos e complexos problemas. Vacilaram os juristas ao abordá-los. Torna-se necessário perquirir, agora, se a Representação Comercial deverá ser considerada um órgão estatal soviético ou uma pessoa moral distinta do Estado russo, quando pratica no estrangeiro atos de comércio.

O Professor Makarov no seu artigo citado distingue que a Representação Comercial exerce duas categorias de funções: reguladoras e comerciais. As primeiras correspondem às atribuições dos cônsules em matéria de comércio e dos agentes comerciais especiais. As segundas dizem respeito à prática de atos pròpriamente mercantis. Quando exerce as primeiras, a Representação Comercial o faz como órgão do Estado soviético. Ao praticar, porém, atos de natureza comercial, adquire personalidade jurídica como comerciante.

MAKarov afirma sem vacilação:

"Les représentations commerciales sont-elles des commerçants au sens du droit commercial? La question est controversée. Nous estimons, cependant, que la nature même de leur activité oblige à les considérer comme commerçants au sens du droit commercial" (p. 535).

Ao contestar a opinião de Petchorine, que sugeria fôsse a Representação Comercial considerada "sociedade de fato", esclareceu MaIKarov o seu próprio pensamento:

"Les représentations commerciales sont des institutions d'État dont le gouvernement est reconnu de jure: on peut les assimiler aux personnes morales de droit privé, mais il n'est pas besoin de les considérer comme sociétes de fait" (p. 537). 
Apoia-se em Korezki para concluir, finalmente, que "o direito soviético reconhece a personalidade moral das Representações Comerciais” (p. 534).

Mas declara, ao mesmo passo, que "l'état soviétique apparait sur le marché étranger comme commerçant professionel" (p. 534).

Freund, relatando como o problema foi situado na Alemanha, adianta:

"La question de savoir si les Représentations commerciales ont la qualité de commerçant n'a été discutée, à ce que nous sachions, qu'en Allemagne. La question est controversée. Le point de vue soviétique est hostile à cette conception, toujours pour la même raison, à savoir que les Représentations font partie intégrante des Ambassades. La doctrine est dans le sens contraire, car l'activité principale de la Représentation se ramène à faire des actes de commerce. Or, le droit allemand admet que l'État soit traité comme commerçant en tant qu'il fait des actes de commerce" (p. 21).

TAGER, examinando o tratado franco-soviético, afirma:

"Ces dispositions contribuent à placer l'État soviétique, en tant qu'il réalise pratiquement le monopole du commerce étranger, dans la situation d'un commerçant ordinaire. En effet, il fait à titre habituel des actes de commerce; il est donc commerçant dans les termes mêmes du droit comum. D'après le traité, l'Etat soviétique ne jouit pas d'immunité fiscale; il payera ainsi les impôts comme tout commerçant; la compétence du tribunal de commerce à son égard est certaine" (Journal du Droit International, 1934, p. 29).

Declara, em suas conclusões finais, que o referido tratado colocou "o Estado, titular do monopólio, como comerciante e o submeteu, como tal, ḋ jurisdição e às vias de execucão do direito comum" (p. 35).

Acha, todavia, TAGEr que o Estado russo não precisa matricular-se no Registro do Comércio porque a publicidade visada pela lei através dêsse Registro fôra efetivada, 
de outra forma, com a publicação feita no Diário Oficial do nome das pessoas autorizadas a assinar pela Representação Comercial. Trachtenberg pensa que, após o tratado, não mais se justifica o Registro. Mas, no seu artigo indicado, menciona uma decisão do Tribunal de Comércio do Sena, França, e da Câmara de Comércio de Istambul, Turquia, exigindo-o.

Resta indagar qual seria a situação em face do direito positivo brasileiro, tendo-se sempre em vista o convencionado no Protocolo.

Esste especifica, no art. $3 .^{\circ}$, que caberão à Representação Comercial três funções: a) promover a expansão do comércio entre o Brasil e a U.R.s.s.; b) representar os interêsses da U.R.S.S. no Brasil, no que se refere ao comércio entre os dois países; e c) exercer em nome do Govêrno da U.R.S.S., o comércio entre os dois países.

A primeira tarefa, como se vê, é a que se costuma, habitual e geralmente, consignar aos representantes comerciais. A segunda inclui-se na atividade normal dos cônsules. Sòmente a terceira marca a completa transformação havida nos usos e costumes do comércio externo. Assinala a tipicidade excepcional da posição soviética.

Não se pode, porém, concluir daí, como vinha pretendendo a doutrina russa, que só a Representação Comercial exerce o comércio exterior. Não, ao contrário. Existem, também, outras organizações soviéticas, com personalidade jurídica autônoma, que atuam no comércio exterior. É o que torna patente o disposto no art. $4 .^{\circ}$ do Protocolo, onde tais organizações soviéticas vêm expressamente mencionadas. Tem-se, assim, de aceitar, obrigatòriamente, três cateyorias de personalidades russas, distintas, atuando no Brasil: $1^{\circ}$ ) o Govêrno soviético; $2^{\circ}$ ) a Representação Comercial; e $\left.3 .^{\circ}\right)$ as organizações soviéticas autônomas. Registre-se, ademais, que cada uma dessas pessoas jurídicas tem responsabilidade autônoma, delimitada de modo expresso, bem como patrimônio próprio $e$ individualizado. 
Diz o Protocolo, no art. $44^{\circ}$, que " a Representação Comercial atua em nome do Govêrno da U.R.S.s.".

Acrescenta, a seguir, que "o Govêrno da u.R.s.s. assume, pois, a responsabilidade por tôdas as transações comerciais que no Brasil forem concluídas ou garantidas pela Representação Comercial, mediante assinatura dos documentos respectivos por duas pessoas devidamente credenciadas".

Esclarece, finalmente, que "a Representação Comercial comunicará ao Govêrno brasileiro o nome das pessoas que credencie para êsse fim, bem como a extensão dos poderes que lhes confira, no tocante a quaisquer obrigações comerciais assumidas em nome da Representação Comercial. O Govêrno brasileiro publicará no "Diário Oficial" dos Estados Unidos do Brasil, os nomes das pessoas designadas, bem como os poderes e a extensão que lhes haja sido conferida. Tais poderes serão considerados válidos até que, no "Diário Oficial", seja publicada notícia de sua revogação ou alteração.

Delineia-se, assim, com cristalina nitidez, a figura de um autêntico mandato comercial. De um lado, como mandante, o Govêrno russo. Do outro lado, como sua mandatária, a Representação Comercial. Êste mandato se exerce em lugar fixo e determinado: o Brasil. Tem como objeto específico transações comerciais e só obriga o mandante nos limites dos poderes expressamente conferidos. Impossivel, pois, negar-se a existência de duas pessoas jurídicas, claramente distintas.

A terceira, ou melhor, as outras pessoas juridicas existentes, são as denominadas "Organizações soviéticas com personalidade juridica autônoma, segundo o direito soviético", também referidas no art. $4^{\circ}$ do Protocolo. Estas possuem, sem dúvida, personalidade própria, responsabilidade autônoma e patrimônio individual especificado. Tanto assim, que o art. $4 .^{\circ}$ do Protocolo alerta:

"Fica entendido, entretanto, que quando não houver tal garantia da Representação Comercial - no caso de transações concluídas por Organizações soviéticas com per- 
sonalidade jurídica autônoma, segundo o direito soviético - serão responsáveis por essas transações, apenas as Organizações soviéticas autônomas que delas participaram, as quais por elas responderão com seus bens e propriedades. Nesses casos, nem o Govêrno russo, nem a Representação Comercial, nem qualquer outra Organização soviética autônoma, que não seja parte na transação, por ela assumirá a responsabilidade".

Está, dessa forma, feita de modo categórico a distinção entre as pessoas jurídicas diferentes: o Govêrno da U.R.S.S., a Representação Comercial e as Organizações autônomas soviéticas.

TAGER chama, ainda, a atenção para a forma restritiva do mandato outorgado pelo Estado russo à Representação Comercial, o qual só lhe permite praticar, sob sua responsabilidade, "transações comerciais". Elucida, também, que na linguagem jurídica esta expressão compreende sómente. os atos de comércio de natureza contratual e voluntária. Adverte, por isso, que, se os que agirem em nome da Representação Comercial ultrapassarem os limites dêsse mandato, deverão responder apenas individualmente pelos atos praticados. Mas, conclui TAGER, como foram equiparados aos diplomatas, passaram a gozar da respectiva imunidade e, dêsse modo, a responsabilidade no caso "se tornará palavra vô".

O jurista francês assinala, mais, que esta delimitação de responsabilidade tende a propiciar o surgimento de delicadas e difíceis controvérsias jurídicas. Refere-se, por exemplo, às hipóteses ligadas à responsabilidade civil, aos delitos e quase-delitos. Novos aspectos jurídicos poderiam, ainda, ser suscitados em conseqüência da restrição referida. Isso, no entanto, ampliaria muito o plano do presente estudo, com o perigo de desviá-lo de sua primordial finalidade.

À vista do exposto, deve-se agora perquirir, em face da lei comercial brasileira - a única e exclusiva que se pode aplicar à espécie, se seria admissível considerar-se o Estado 
russo, ou a Representação Comercial soviética, ou ambos, como comerciantes.

A resposta, em sentido contrário, parece não suscitar nenhuma dúvida. $O$ direito comercial brasileiro não permite se atribua ao Estado a qualidade de comerciante. Se alguma vacilação houvesse a êsse respeito, a lição de CARvalHo DE Mendonça a destruiria por completo. Ei-la:

"Sem desconhecer o elevado fim do Estado, é ponto atualmente aceito, que os seus atos de gestão podem revestir o caráter de atos de comércio e ser regidos pela legislação comercial.

Assim, o Estado cria, ao lado da esfera da ação que lhe é própria, outro domínio jurídico, no qual trata com pessoas de direito privado, colocando-se em pé de igualdade com estas. $O$ Estado, entretanto, nunca poderá ser tido como comerciante. Não foi instituído para exercer essa profissâo". (Tratado de Direito Comercial Brasileiro, 1937, 3. ${ }^{a}$ edição, vol. $2^{\circ}$, p. 103).

Não admite, portanto, que o Estado assuma a qualidade de comerciante nem mesmo quando exerça, habitualmente, atos de comércio. Certo que o Estado não poderia incidir em falência. Se se pudesse admitir, por hipótese, a sua falência, como os seus bens e rendas são impenhoráveis e insuscetíveis de arrecadação, ficaria a mesma sem objeto. Esste o ensinamento do ilustre comercialista pátrio.

É preciso ter-se em conta que se concebe a prática de atos comerciais pelo Estado exclusivamente no âmbito interno da sua atuação. Estes atos nunca poderiam constituir expressão da própria soberania estatal. Nessa atividade privada nem se vislumbraria também o seu poder de império. Pelo contrário, o Estado seria forçado a dêle abrir mão a fim de colocar-se em pé de igualdade com os demais comerciantes, nacionais ou estrangeiros.

Resta examinar a situação da Representação Comercial, cuja personalidade jurídica se deve reconhecer e separar da atribuída ao Estado russo. Este é, por certo, pessoa jurídica de direito público. $\mathrm{O}$ direito soviético talvez auto- 
rize classificar-se aquela como pessoa jurídica de direito privado, tal como parece ocorrer com as Organizações soviéticas mencionadas no art. $4 .^{\circ}$ do Protocolo. O tema é sugestivo, mas aprofundá-lo fugiria ao escopo das atuais considerações. O Protocolo colocou, todavia, a Representação Comercial numa posição que inibiu se a qualifique comerciante. Sua situação é a de mera mandatária do Govêrno russo. Nessas condições, não se enquadra, jamais, na categoria de comerciante. Waldemar Ferreira é categórico: "Quem exercita o comércio em nome e por conta de outrem comerciante não é" (Tratado de Direito Mercantil Brasileiro, 1939, vol. 2. ${ }^{\circ}$, p. 49).

Robustece, com esta citação, a sua afirmativa:

"Sempre se entendeu assim: qui nomine alieno exercet mercaturam, non comprehenditur sub statuto loquente mercatoribus" (op. cit., p. 50).

Não tem, por isso, sentido a isenção do art. $10^{\circ}$ do Protocolo:

"A Representação Comercial não estará sujeita às leis e regulamentos sôbre registro comercial".

Não sendo comerciante, a Representação Comercial não estaria, de fato, sujeita às exigências daquela natureza.

$O$ que não consegue, porém, encobrir o Protocolo, é o seu intento absurdo e despropositado de criar uma figura "sui generis" de comerciante a ser impressa a uma pessoa jurídica de direito público, o Estado russo, que faz empenho de exercer, como ato de sua soberania, o comércio no território brasileiro.

Não há, todavia, motivo para que se conspurquem princípios jurídicos fundamentais e de há muito assentes, a fim de que se atenda impertinente e descabida a exigência bolchevista.

Nem se alegue que, fora da hipótese acima, não possa a Rússia promover o seu comércio exterior. Se não quiser credenciar uma firma brasileira para representá-la, poderá organizar uma sociedade ou companhia russa com esta fi- 
nalidade. E depois, conforme preceitua a legislação comercial brasileira - Decreto-lei n. ${ }^{\circ}$ 2.627, de 26 de setembro de 1940, - virá a exercer, de modo normal e conveniente, o comércio neste país.

Não se compreende nem se justifica, contudo, que, para manter comércio com a Rússia, seja o Brasil obrigado a sujeitar-se às exigências de um sistema monopolista revolucionário, em inteiro desacôrdo com os preceitos do seu ordenamento constitucional.

c) Submissão da Representação Comercial ḋ Jurisdição Local.

Não é pacífica a assertiva de que a Representação Comercial sujeita-se, em tôdas as suas atividades, à jurisdição local do país onde opera. Como o seu mandato é específico e a Rússia insiste em considerá-la organismo do Estado ligado à Embaixada Soviética, chegou-se a pretender que, fora dos limites do seu mandato específico, permanecerá acobertada pela imunidade diplomática. Esta controvérsia extravasa, contudo, do assunto ora em foco. Fato é que a Representação Comercial fica sujeita aos órgãos da jurisdição local onde exerce sua atividade mercantil.

O Protocolo preceitua no art. $5^{\circ}$ :

“A Representação Comercial goza dos privilégios e imunidades que the são conferidos no art. $1^{\circ}$, com as seguintes exceções: $1^{\circ} .^{\circ}$ ) as questões surgidas de transações comerciais, concluídas ou garantidas no Brasil pela Representação Comercial, nos têrmos do $\S 2 .^{\circ}$ do $\operatorname{art.} 44^{\circ}$, serão da competência da justiça brasileira, caso não haja estipulações sôbre a arbitragem, ou outra em contrário nos contratos específicos, ou as partes interessadas cheguem a entendimento diverso a respeito. Não caberão, nesse caso, medidas judiciais que impeçam a livre disposição dos bens de propriedade da Representação".

Dai haver surgido a dúvida indicada. Admite-se, também, a livre eleição do fôro pelas partes contratantes, bem como o apêlo à arbitragem. Em qualquer dessas duas 
situações, não se poderá impedir "a livre disposição dos bens de propriedade da Representação".

Ésses bens não serão, por certo, imóveis porque, devido a expresso preceito constitucional pátrio, a Representação Comercial, como órgão estatal russo, não poderia possuí-los localizados no Brasil. $\mathrm{E}$ isso, desde que aquela fôsse assim considerada. Prossegue o Protocolo, no mesmo artigo:

"No que se refere aos procedimentos judiciais determinados pelos 'Tribunais brasileiros, de acôrdo com o disposto no parágrafo anterior, o Govêrno da U.R.S.s. não invocará em favor do Chefe da Representação Comercial (o Representante Comercial), seus dois suplentes ou mais funcionários da mesma, os privilégios e imunidades indicados no art. $2 .^{\circ}$ e se compromete a autorizar o Chefe da Representação Comercial (o Representante Comercial), e, na sua ausência, o Chefe substituto da mesma, a representar o país, a fim de que o Tribunal possa proceder as medidas judiciais de acôrdo com as demandas propostas nos têrmos do parágrafo anterior".

Verifica-se ter sido sempre repetida a restrição que marca sòmente as questões oriundas de transações comerciais. Continua o Protocolo, nesse artigo:

"A execução das sentenças jurídicas relativas às transações de que seja parte a Representação Comercial poderá incidir sôbre todos os bens do Estado soviético no Brasil, particularmente sôbre os bens, direitos e interêsses oriundos de transações efetuadas ou garantidas pela Representação Comercial. Não incidirá, porém, sôbre os bens pertencentes às Organizações mencionadas no $\S 44^{\circ}$ do art. $4 .^{\circ}$, que não houverem participado de transação garantida pela Representação Comercial. Segundo a praxe internacional, não serão objeto de procedimento judicial, de qualquer natureza, os bens e locais destinados exclusivamente ao funcionamento, no Brasil, da Embaixada, da Representação Comercial e do Consulado soviéticos, bem como os móveis e pertences nelas situados". 
Além dêsses bens excepcionados, que outros poderiam, na verdade, responder pelos compromissos soviéticos? Quais os que restam ao Estado soviético no Brasil? Quais direitos e interêsses, oriundos das transações efetuadas ou garantidas pela Representação Comercial?

Revela-se, pois, esta pseudo garantia simplesmente ilusória e não colimará jamais o fim a que parece estar consignada.

\section{O Protocolo como Instrumento do Acôrdo Comercial.}

Torna-se necessário, antes de mais nada, fixar que, através do referido Protocolo, o Govêrno brasileiro, representado pelo Ministro das Relações e Negócios Exteriores, concedeu à Representação Comercial soviética, os seguintes privilégios, imunidades e isenções :

$\left.1^{\circ}\right)$ equiparou o escritório da Representação Comercial soviética da cidade do Rio de Janeiro, a uma sede de Missão Diplomática estrangeira, reconhecendo-lhe os respectivos privilégios e imunidades (art. $10^{\circ}$ );

$\left.2^{\circ}\right)$ concedeu ao Representante Comercial, aos seus dois suplentes e demais funcionários que constarem da "Lista Diplomática", os privilégios e imunidades outorgados aos membros do corpo diplomático (art. 2..$^{\circ}$ );

$\left.3 .^{\circ}\right)$ isentou os cidadãos soviéticos, funcionários da Representação Comercial, do pagamento do impôsto de renda relativo aos salários que perceberem do Govêrno soviético pela execução de suas funções, nas quais se inclui a prática de atos mercantis (art. 2.. );

$\left.4^{\circ}{ }^{\circ}\right)$ criou, através de preceitos genéricos, uma esdrúxula figura de comerciante e atribuíu-a à Representação Comercial, apesar de considerá-la órgão do Estado russo; e

$\left.5^{\circ}\right)$ dispensou a Representação Comercial do cumprimento das leis e regulamentos relativos ao Registro Comercial (art. $1^{\circ}$ ).

Formulam-se, agora, as seguintes indagações: é o Protocolo instrumento jurídico hábil para tão relevantes reso- 
luções? Não dependem essas resoluções, pela sua natureza e transcendência, da aprovação do Congresso Nacional? Poderá o Congresso Nacional aprovar, indistintamente, tôdas essas resoluções?

A resposta a essas perguntas é negativa, em face do ordenamento jurídico brasileiro, e, sobretudo, dos preceitos constitucionais vigentes no país. Fundamenta-se e justifica-se pelas razões a seguir expostas.

É tido o "protocolo", na técnica diplomática, como documento em que se anotam decisões de Congressos internacionais. Dá-se-lhe, outrossim, o significado de instrumento em que se complementam os dispositivos de tratados e convenções internacionais. Êste caráter suplementar atesta, desde logo, a natureza subordinada e secundária dos seus preceitos e dos assuntos neles contidos.

o Dictionnaire Diplomatique, publicado pela Academia Diplomática Internacional, assim o define:

"Protocole - Depuis le Congrès de Vienne, les procèsverbaux des Congrès internationaux portent le nom de "protocoles".

Les protocoles sont également les actes qui mentionnent une décision prise par des diplomates, réunis en conférences, sur une question d'ordre international. C'est un instrument diplomatique, enregistrant un accord sur certains points d'une question, et qui n'a pas la forme du traité ou de la convention".

Henri Capitant, no seu autorizado Vocabulaire Juridique, Paris, 1936, registra:

"Protocole - Actes relatant résolutions d'une conférence, d'une assemblée, d'un congrès international et par extension ces resolutions elles mêmes. Ex.: le protocole de Genève".

Esta, portanto, a acepção exata da palavra "protocolo" na linguagem diplomática. Recorde-se que o célebre protocolo de Genebra foi um acôrdo multilateral, firmado entre representantes estrangeiros, especialmente credenciados para tal fim. Nem se deixou, por esta circunstância, de exigir 
fôsse, na forma do direito interno, ratificado pelas Altas Partes contratantes e isso como condição sine qua non de sua eficácia. Perdeu, porém, sua maior significação desde que o Govêrno inglês o rejeitou.

Em seu Dicionário de Tecnologia Juridica, Rio de Janeiro, 1948, Penro Nunes consigna:

"Protocolo - 6 - Registro das deliberações ou das atas de um congresso diplomático".

Como já se mencionou, o têrmo "protocolo" também serviu para o instrumento utilizado na fixação de medidas e providências secundárias, decorrentes de tratados e convenções internacionais.

Daí a menção de Pedro Orlando, no seu Novíssimo Dirionário Jurídico:

“Protocolo - é uma espécie de convenção entre duas nações, dois Estados internacionais, mas de menor importância do que o tratado $e$ a convenção pròpriamente ditos".

Ao tratar da terminologia dos acordos internacionais, Hildebrando Accioly cataloga os vários sentidos dêsse têrmo:

“O protocolo é o documento no qual se consigna o acôrdo a que vão chegando ou chegaram os negociadores de um tratado; ou serve para designar um acôrdo menos formal do que os tratados; ou indica o ato final ou de encerramento de uma conferência internacional; e já tem sido usado como denominação de instrumentos internacionais de grande importância (Por exemplo: o Protocolo de Genebra, de 1924)", (Manual de Direito Internacional Público, 1953, p. 259).

Rubens Ferreira de Mrllo assinala, também, que os atos referentes aos acordos internacionais apresentam-se "sob diversos nomes, tais como, tratados, convenções, declarações, protocolos, convênios, acordos, ajustes, modus vivendi, concordatas, reversais, trocas de notas, etc., segundo a forma que tenham, o objetivo a que se proponham, ou o texto das suas disposições".

Esclarece, em seguida, que "essa nomenclatura" estabelece, sob certos aspectos "entre os mencionados instru- 
mentos uma espécie de hierarquia, cujo primeiro lugar pertence aos tratados" (T'ratado de Direito Diplomático, Rio de Janeiro, 1949, p. 39).

$\mathrm{O}$ autor mantém o mesmo pensamento no seu Dicionário de Direito Internacional Público, Rio de Janeiro, 1962.

Ninguém, no entanto, mais autorizado do que Afonso Arinos de Melo Franco, na qualidade de Professor da Faculdade Nacional de Direito da Universidade do Brasil, ex-Ministro das Relações e Negócios Exteriores e atual Embaixador brasileiro na onU, para dar, em definitivo, a acepção técnica e exata desta palavra. Foi o que fêz ao ministrar uma aula no Curso de Aperfeiçoamento de Diplomatas do Instituto Rio Branco, órgão oficial do Itamarati. Expondo como haviam sido classificados os atos internacionais submetidos à aprovação do Congresso brasileiro afirma :

"Os protocolos são os únicos denominados em obediência à classificação assente na doutrina. Os dez que examinei se destinam todos a emendar ou complementar atos anteriores, e esta é, na opinião dos autores, a finalidade própria dos chamados protocolos no direito internacional" (Estudos de Direito Constitucional, Rio de Janeiro, 1957, p. 269).

Pode-se dizer, em síntese, que o Protocolo está para o Tratado, assim como o Decreto para a Lei. Pode o Protocolo complementar o Tratado, até mesmo suprí-lo, mas, sempre dentro de uma restrita órbita que lhe é prefixada.

Seria inexato alegar-se que o Protocolo citado complementara, apenas, o acôrdo de comércio e pagamento feito, na mesma data, entre o Brasil e a u.R.S.s.. O Tratado que consigna aquêle entendimento foi, de modo insofismável, ultrapassado em muito pelo Protocolo. Basta verificar que em nenhum dos artigos dêste Tratado, já aprovado pelo Congresso Nacional, se fêz, sequer, discreta menção a regalias, imunidades e privilégios diplomáticos que devessem ser outorgados pelo Brasil à Representaçâo Comercial soviética. 
Pelo contrário, o art. $5 .^{\circ}$ dêsse Tratado estabelece que:

"Respeitada a legislação do Brasil, os cidadãos soviéticos, bem como as pessoas jurídicas organizadas em conformidade com as leis vigentes na U.R.S.S., gozarão, quanto $\dot{a}$ proteção de sua pessoa e propriedade, do mesmo tratamento concedido aos cidadãos e às pessoas jurídicas de qualquer outro país no exercício de suas atividades comerciais no território dos Estados Unidos do Brasil, diretamente ou através de representantes que êles escolherem, e nas condicões em que essas atividades forem permitidas pelas normas vigentes no Brasil".

Ora, o Protocolo contrariou, de maneira flagrante, esta regra basilar firmada no Tratado, pois concedeu, em desacôrdo com o texto expresso, tratamento excepcional tanto para a Representação Comercial como aos seus funcionários. Assegurou-lhes privilégios, imunidades e isenções legais. Que outro país desfruta, no Brasil, de idêntica situação? A Itália? A França? Portugal? O Canadá? A Inglaterra? Os Estados Unidos?

Nem mesmo os países do continente sul-americano receberam, jamais, do Brasil, tão extraordinárias e extensas regalias. E note-se que, na Segunda Reunião de Consulta entre os Ministros de Relações Exteriores das Repúblicas americanas, realizada com o fim de estreitar os laços de amizade e relações entre todos os povos dêste continente, ficoul estabelecido que as Nações americanas manteriam "sua adesão aos princípios liberais do comércio internacional, com fins pacíficos, baseados na igualdade de tratamento $e$ procedimentos justos e equitativos no intercâmbio" (Ata final subscrita em Havana, no dia 30 de julho de 1940, Revista do Colégio de Advogados ide Havana, vol. 4.", 1941, p. 98).

Estes princípios, constantes de um compromisso interamericano, foram também menosprezados e inifringidos pelo Protocolo. Resulta patente que um acôrdo da natureza do que foi feito com a Rússia, de tão graves e transcenden- 
tais conseqüências, nunca poderia ter sido rotulado como um simples "protocolo". Pela natureza e importância dos assuntos abordados, o seu instrumento jurídico deveria ser um tratado ou uma convenção. E no caso seria, por certo, "tratado-lei", conforme o designariam os internacionalistas. lsso porque no Protocolo foram editadas regras de direito, segundo se viu.

Capitant, na sua citada obra, refere-se a duas espécies de tratado:

"Traité de commerce - ayant pour objet de régler les conditions des échanges de marchandises et les transations commerciales entre les sujets des Etats contractants".

"Traité d'établissement - réglant les conditions de résidence, de commerce et en général, d'activité économique des ressortissants respectifs des états contractants sur leurs territoires. Ces traités contiennent aussi souvent des stipulations relatives à la compétence des consuls".

Não padece, no entanto, a menor dúvida que as resoluções registradas no referido Protocolo, quer se o chame de "protocolo" ou "tratado", subordinam-se à decisão definitiva do Congresso Nacional.

E conhecida a controvérsia entre o Professor Haroldo Valladão e o Embaixador Hildebrando Accioly sôbre a necessidade de aprovação dos ajustes internacionais pelo Congresso brasileiro.

Sustentou o Professor VAlladão ser imprescindível esta aprovação. Contestou-lhe a tese, o Embaixador Accioly.

$O$ primeiro expressou o seu pensamento num parecer exarado em resposta à consulta que lhe dirigira o Ministro das Relações e Negócios Exteriores. No decorrer do seu arrazoado, discordou de Hildebrando Accioly que sustentara " possibilidade de ser o Brasil parte em atos internacionais, que não dependem de aprovação do Congresso Nacional". Este ponto de vista fôra expendido pelo Embaixador Accioly em artigo publicado sôbre a Ratificação e a Promulgação de Tratados, no n. 7 do Boletim da Sociedade Brasileira de Direito Internacional, em 1948. 
Depois de desenvolver o raciocínio que motivara o seu convencimento, o Professor Valladão demonstrou, "ex-abundantia", que a sua tese apoiava-se, ainda, na autoridade de eminentes juristas estrangeiros e pátrios, que a sufragavam no mesmo sentido.

Replicou-lhe o Embaixador Accioly, em novo artigo publicado no citado Boletim, n. $^{\circ 8} 13$ e 14, em 1951, mantendo e procurando justificar a sua opinião anterior.

Não permitem as exíguas dimensões do presente trabalho seja tentada, sequer, uma rápida síntese de tão alto e instrutivo debate jurídico. Isso não impede, no entanto, se dê agora completo apoio à tese do Professor Valladão, acrescentando ainda, e sem temor de contradita, que é tranqüila, pacífica no Direito Constitucional brasileiro. O Professor Valladão citou em abono de sua assertiva as lições de Clóvis Bevilaqua (Direito Público Internacional, 1939, tomo $2 .^{\circ}$ p. 17), Barbalho (Comentários, 1924, p. 149), Aristides Milton (A Constituição do Brasil, 1898, p. 251) e Sette CÂmara (The Ratification of International Treaties, 1949, p. 36). Poderia ter referido, também, em seu favor, o ensinamento de RuY Barbosa (Comentários, 1933, vol. 2, p. 520), Aurelino Leal (Teoria e Prática da Constituição Federal Brasileira, 1925, p. 625) e Carlos Maximiliano (Comentários, 1918, p. 359). Como se vê, são todos os insignes comentadores da Constituição Brasileira de 1891 unânimes no mesmo modo de pensar.

Na resposta ao Professor VAlladÃo, dada através do artigo Ainda o Problema da Ratificação dos Tratados em Face da Constituiçẫo Federal Brasileira, o Embaixador Accioly, referindo-se já à Constituição Brasileira de 1946, faz duas afirmativas que exigem, "data venia", reparo. Declara:

"Como quer que seja, no sistema presidencial, a situação é outra. A responsabilidade pela orientação e execução da política externa cabe simplesmente ao Poder Executivo". 
“Em nossa Constituição de 1946 (art. 87, vi), está dito claramente que "compete privativamente ao Presidente da República": "manter relações com Estados estrangeiros" (p. 23).

Mais além, conclui :

"A tese da competência privativa é perfeitamente razoável. Se a matéria de um acôrdo é das que cabem peculiarmente dentro das atribuições constitucionais do Poder Executivo e dado que a èste é que compete o exercício das relações com outros Governos, não há por que se lhe deva negar a autoridade para celebrar o dito acôrdo e pô-lo em vigor sem intervenção do Poder Legislativo" (p. 31).

É preciso não misturar, e a Constituição brasileira de 1946 jamais confundiu, a "manutenção de relações com Estados estrangeiros" com a "celebração de tratados e convencões internacionais" São duas coisas diversas, apartes.

Procurei, em trabalho anterior, precisar o exato sentido do disposto no art. 87, n. $^{\circ}$ vI, da referida Constituição, escrevendo:

"O Presidente da República, por exercer o cargo de maior relêvo nacional, encontra-se na posição mais adequada para representar a Nação nas suas relações com os países estrangeiros.

Sua alta hierarquia situa-o no mesmo plano dos chefes de Estado com os quais terá, eventualmente, de tratar. Ésses contactos serão, na maioria das vêzes, apenas amistosos, visando, através de homenagens e gestos de cortesia, maior aproximação e entendimento entre os povos.

Adquirirão relêvo quando se destinarem ao recebimento de credenciais de embaixadores ou de delegados plenipotenciários especiais, dando início, assim, à representação estrangeira no país ou à missão extraordinária.

Estas atividades possuem, todavia, caráter mais honorífico e o Presidente da República, ao praticá-las, simboliza e representa a Nação, que se encarna, de certa forma, na sua própria pessoa. Trata-se, na verdade, de meros atos de 
presentação, como os denomina Pontes de Miranda, os quais decorrem da natureza específica do cargo e incluem-se, por isso, na órbita de sua competência privativa, independendo de prévio consentimento ou confirmação posterior do Congresso Nacional" (Parlamentarismo e Presidencialismo, 1962, p. 67).

Assinalei, ademais, a competência privativa do Presidente da República para "permitir que brasileiros aceitem de Govêrno estrangeiro, pensão, emprêgo ou comissão".

Ainda na esfera de política exterior, esclareci que "as demais funções são de maior porte e envolvem decisões políticas que comprometem o Govêrno. Por isso, dependem do necessário pronunciamento do Congresso Nacional, que lhes dá prévio assentimento ou considera-as em exame posterior" (Op. cit., p. 68).

As atribuições presidenciais, nessa esfera, que requerem anterior autorização congressual, são: declarar guerra e permitir a permanência ou o trânsito de Fôrças estrangeiras no território do país (art. 87, n. ${ }^{\circ s}$ viII e x). Dependem, porém, da aprovação posterior do Congresso Nacional as relativas à celebração de tratados e convenções internacionais e o estabelecimento da paz (art. 87, $\mathrm{n}^{\circ{ }^{\mathrm{B}}}$ VII e $\mathrm{Ix}$ ),

Quando a Constituição postula que as atribuições do art. 87 e seus números competem "privativamente ao Presidente da República" quis, sem dúvida alguma, fixar que o ato lhe pertence de modo exclusivo, e por isso é, a maioria das vêzes, de sua iniciativa.

Tanto é assim que, no plano nacional, duas atribuições "privativas" do Presidente da República ficaram também subordinadas à aprovação do Senado Federal : a nomeação e demissão do Prefeito do Distrito Federal e dos membros do Conselho Nacional de Economia (art. 87, n. ${ }^{\circ}$ Iv, combinado com os arts. 26 ; $\S \S 10^{\circ}$ e $20^{\circ}$, e $205, \S 10^{\circ}$, da Constituição Federal).

Esse o ensinamento inconteste dos mais ilustres comentaristas da Constituição de 1946. Verifique-se: PONTES DE 
Miranda (Comentários, 1947, p. 65), Themistocles CavalCANTI (A Constituição Federal Comentada, 1948, vol. 2. p. 129) e Eduardo Espínola (Constituição dos Estados Unidos do Brasil, 1952, vol. 1. ${ }^{\circ}$, p. 359).

Por êsse motivo, o Embaixador Accioly não pôde se valer da opinião de nenhum dêles na sustentação do seu isolado ponto de vista. Mas, mesmo de acôrdo com a sua tese, o referido Protocolo não ficaria dispensado da posterior aprovação pelo Congresso Nacional, porquanto o Embaixador Accioly teve o cuidado de esclarecer:

"Sem falar, porém, na praxe americana, pode dizer-se, de conformidade com a doutrina mais corrente, que a ratificação não é geralmente exigida para os seguintes atos internacionais: a) os acordos sôbre assuntos que sejam da competência privativa do poder executivo; $b$ ) os concluídos por agentes ou funcionários que tenham competência para isso, sòbre questões de interêsse local ou de importância restrita; $c$ ) os que consignam simplesmente a interpretação de cláusulas de um tratado já vigente; $d$ ) os que decorrem, lógica e necessàriamente, de algum tratado vigente e são como que o seu complemento; $e$ ) os de "modus vivendi", quando têm em vista apenas deixar as coisas no estado em que se encontram ou estabelecer simples bases para negociações futuras. A êsses casos, é freqüente que na prática, se acrescentem outros, como por exemplo, os de ajuste para prorrogação de tratado antes que êste expire e as chamadas declarações de extradição, isto é, as promessas de reciprocidade em matéria da extradição, feitas por simples troca de notas" (Boletim citado, p. 8).

Vicente Marotta Rangel, em cuidadoso estudo sôbre $L a$ procédure de conclusion des acords internationaux au Brésil, publicado na Revista da Faculdade de Direito, da Universidade de São Paulo, 1960, vol. 40, depois de haver examinado a questão, revelando, nesse passo, novas fontes, chega também à conclusão de ser indispensável a aprovação do Congresso Nacional nos ajustes internacionais. 
Atinge-se, agora, o derradeiro e mais grave problema: teria o Congresso Nacional competência para aprovar as aludidas resoluções constantes do Protocolo?

Indispensável, desde logo, distinguir.

O Congresso Nacional poderia, sem dúvidar, mediante a aprovação do citado Protocolo, criar uma figura especial de comerciante para atribuí-la à Representação Comercial russa.

Ser-lhe-ia, da mesma forma, permitido equiparar a Representação Comercial soviética a uma Missão Diplomática, concedendo-lhe e ao seu pessoal os respectivos privilégios, isenções e imunidades.

Estaria, no entanto, impedido o Congresso Nacional de conceder privilégios à Representação Comercial que, por qualquer modo, viessem a ferir preceitos constitucionais. Agiria assim, por exemplo, se pretendesse criar desigualdade de condições para a prática da profissão de comerciante ou beneficiar pessoas físicas ou jurídicas estrangeiras em detrimento de cidadãos ou pessoas juridicas brasileiras ou reconhecer monopólio estatal estrangeiros que comprometa a liberdade do comércio nacional.

Na primeira hipótese, infringiria o disposto no art. 141, $\S 14$; na segunda, o $\S 10^{\circ}$ do mesmo artigo e na terceira, o art. 149, todos da Constituição Federal. Seu ato revelarse-ia, portanto, nulo, uma vez que eivado de inconteste inconstitucionalidade.

Vale recordar a lição de Francisco de Campos:

"O principio de igualdade perante a lei, tem, assim, por principal destinatário, o legislador. Este não pode legislar por via de ordens ou medidas destinadas a reger apenas os casos que êle entenda privilegiar, excluindo do tratamento que dá a êstes os casos que com êles estão em relação de identidade ou de igualdade" (Direito Administrativo, 1958, vol. $2 .^{\circ}$, p. 189 ).

Mais adiante:

"A igualdade perante a lei rege a aplicação da lei, precisamente porque o princípio em que é constitucionalmente 
enunciada rege o legislador e constitui uma regra destinada a disciplinar os seus impulsos ou a evitar a versatilidade e o arbítrio na legislação" (Op. cit., p. 190).

Marca a amplitude do princípio:

"Como o princípio de igualdade perante a lei obriga o legislador e, em seguida a êste, a autoridade incumbida de aplicar a lei, no momento de sua aplicação, particularmente quando feita por via judicial, é dever do juiz aplicá-la com a extensão ou a amplitude necessária a tornar efetivo o princípio constitucional da igualdade perante a lei, violado pelo legislador" (Op. cit., p. 190).

Se o Congresso Nacional intentasse, pois, dispensar a Representação Comercial soviética "do cumprimento das leis e regulamentos relativos ao Registro Comercial", conforme deseja o Protocolo no art. $1^{\circ}$, estaria, evidentemente, criando uma injustificável e incompreensível desigualdade entre a mesma e o comerciante brasileiro, a firma comercial brasileira e a emprêsa mercantil estrangeira, autorizada a exercer sua atividade no país, de acôrdo com a legislação competente.

Se se dispusesse o Congresso Nacional a isentar cidadãos soviéticos, funcionários da Representação Comercial, do pagamento do Impôsto de Renda, como pretende o Protocolo no art. $2 .^{\circ}$, violaria frontalmente o preceito da igualdade fiscal. Não teria, por sua vez, nenhum cabimento que o Govêrno brasileiro exigisse que seus funcionários pagassem tal impôsto - descontado, às vêzes, até na própria fonte arrecadadora - e dêle dispensasse os funcionários russos da Representação Comercial soviética, que exercem funções mercantis no território do Brasil. Tão grande o absurdo que dispensa maior comentário.

As isenções do Impôsto de Renda que se têm verificado jamais visaram pessoas mas beneficiaram classes, setores especiais de trabalho.

O Desembargador CÂNDIDo LoBo, em acórdão do Tribunal de Justiça do Distrito Federal, do dia 19 de maio de 1955, acentuou que "a isenção fiscal visa aquêle que faz do jorna- 
lismo a sua profissão, não se concebendo que êsse privilégio, constituido em favor de uma classe, possa atingir a quem, pertencendo a ela ou tendo outra profissão, seja também jornalista".

Nem poderia o Congresso Nacional consentir que Estado estrangeiro exercesse, em território brasileiro, o comércio sob forma de monopólio estatal e, pior ainda, como decorrência de uma soberania alienigena, cujo exercício só é possível no plano internacional.

O Congresso Nacional, que tem se mostrado sempre atento, cioso e intransigente na defesa dos interêsses brasileiros, não consentirá, por certo, prevaleçam os enganos e as aberrações jurídicas constantes do referido Protocolo, que se situa como documento diplomático equívoco $\mathrm{e}$ desolador.

Não perca, também, o Congresso Nacional de vista o ensinamento de Martin Ludwig Schlesinger, no seu clássico estudo sôbre El Estado de Los Soviets, Barcelona, 1932, p. 94, em que conclui:

"La Constitución soviética declara tener como Programa la lucha contra el capitalismo y su destrucción, no sólo dentro de los límites de su Estado, sino también fuera de ellos".

São Paulo, 1963 